\title{
The essential oil from Lippia alba induces biochemical stress in the silver catfish (Rhamdia quelen) after transportation
}

\author{
Joseânia Salbego ${ }^{1}$, Alexssandro G. Becker ${ }^{1}$, Jamile F. Gonçalves ${ }^{1}$, Charlene C. Menezes ${ }^{2}$, \\ Clarissa G. Heldwein ${ }^{3}$, Rosélia M. Spanevello ${ }^{4}$, Vania L. Loro², Maria Rosa C. \\ Schetinger ${ }^{2}$, Vera M. Morsch², Berta M. Heinzmann ${ }^{3}$ and Bernardo Baldisserotto ${ }^{1}$
}

This study investigated the effects of the essential oil (EO) from Lippia alba on biochemical parameters related to oxidative stress in the brain and liver of silver catfish (Rhamdia quelen) after six hours of transport. Fish were transported in plastic bags and divided into three treatments groups: control, $30 \mu \mathrm{L} \mathrm{L}^{-1} \mathrm{EO}$ from L.alba and $40 \mu \mathrm{L} \mathrm{L}^{-1} \mathrm{EO}$ from L.alba. Prior to transport, the fish were treated with the $\mathrm{EO}$ from $L$. alba $\left(200 \mu \mathrm{L} \mathrm{L}^{-1}\right.$ for three minutes), except for the control group. Fish transported in bags containing the EO did not have any alterations in acetylcholinesterase, ecto-nucleoside triphosphate diphosphohydrolase and 5'nucleotidase activity in the brain or superoxide dismutase activity in the liver. The hepatic catalase (CAT), glutathioneS-transferase (GST), glutathione peroxidase (GPx), nonprotein thiol and ascorbic acid levels were significantly lower compared to the control group. However, the hepatic thiobarbituric acid-reactive substances, protein oxidation levels and the lipid peroxidation/catalase + glutathione peroxidase $(\mathrm{LPO} / \mathrm{CAT}+\mathrm{GPx})$ ratio were significantly higher in fish transported with both concentrations of the EO, indicating oxidative stress in the liver. In conclusion, considering the hepatic oxidative stress parameters analyzed in the present experiment, the transport of previously sedated silver catfish in water containing 30 or 40 $\mu \mathrm{L} \mathrm{L}^{-1}$ of EO from L. alba is less effective than the use of lower concentrations.

Este estudo investigou os efeitos do óleo essencial (OE) de Lippia alba sobre parâmetros bioquímicos relacionados ao estresse oxidativo em cérebro e fígado de jundiá (Rhamdia quelen), após seis horas de transporte. Os peixes foram transportados em sacos plásticos e divididos em três tratamentos: controle, $30 \mu \mathrm{L} \mathrm{L}^{-1}$ e $40 \mu \mathrm{L} \mathrm{L}^{-1}$ de $\mathrm{OE}$ de L.alba. Antes do transporte, os peixes foram tratados com o OE de L. alba $\left(200 \mu \mathrm{L} \mathrm{L}^{-1}\right.$ por três minutos), exceto para o grupo controle. Os peixes transportados em sacos contendo o $\mathrm{OE}$ não tiveram alterações na atividade da acetilcolinesterase (AChE), ecto-nucleosídeo trifosfato difosfohidrolase (NTPDase) e 5'nucleotidase, em cérebro ou superóxido dismutase (SOD) no fígado. O tiol não proteico (NPSH), os níveis de ácido ascórbico, catalase (CAT), glutationa-S-transferase (GST) e glutationa-peroxidase (GPx) hepáticos, foram significativamente mais baixos em comparação com o grupo controle. No entanto, as substâncias reativas ao ácido tiobarbitúrico (TBARS), os níveis de oxidação proteica e a taxa de peroxidação lipídica/catalase+glutationa peroxidase (LPO/ $\mathrm{CAT}+\mathrm{GPx}$ ) foram significativamente maiores nos peixes transportados com ambas as concentrações de $\mathrm{OE}$, indicando estresse oxidativo no fígado. Em conclusão, considerando os parâmetros de estresse oxidativo do fígado analisados no presente experimento, o transporte de jundiás previamente sedados em água contendo 30 ou $40 \mu \mathrm{L} \mathrm{L}^{-1}$ de OE de L.alba é menos efetivo que utilizando concentrações menores.

Key words: Anesthetics, Antioxidant defenses, Biochemical parameters, Fish transport, Oxidative stress.

\footnotetext{
Departamentos de Fisiologia e Farmacologia ${ }^{1}$, de Química ${ }^{2}$ e de Farmácia Industrial ${ }^{3}$, Universidade Federal de Santa Maria, $97105-900$ Santa Maria, RS, Brazil. josalbego2004@yahoo.com.br (JS) alexssandrobecker@gmail.com (AGB) jamilefabbrin@yahoo.com.br (JFG), charlenemenezes@yahoo.com.br(CCM), vania.loro@gmail.com (VLL), mariachitolina@gmail.com (MRSC),veramorsch@gmail.com (VMM), cissag.hw@gmail.com (CGH), berta.heinzmann@gmail.com (BMH), bbaldisserotto@hotmail.com (BB)

${ }^{4}$ Centro de Ciências Químicas, Farmacêuticas e de Alimentos, Setor de Bioquímica, Universidade Federal de Pelotas, Campus Universitário Capão do Leão, 96010-900 Pelotas, RS, Brazil.rspanevello@gmail.com (RMS)
} 


\section{Introduction}

The transportation of fish in Brazil involves the use of plastic bags. This system has limitations, such as a finite oxygen supply and the build-up of ammonia and carbon dioxide levels (Golombieski et al., 2003; Carneiro et al., 2009; Becker et al., 2012). Generally, fish farmers add pure oxygen to the plastic bags prior to transport, which can cause variations in the dissolved oxygen levels, depress the metabolic rate and provoke blood flow rearrangement and effective methods of energy production (Nilsson \& Renshaw, 2004).

The acetylcholinesterase (AChE) is an important regulatory enzyme, which hydrolyses acetylcholine, a neurotransmitter with important role in the regulation of cognitive functions, mainly found in the brain, muscles, erythrocytes and cholinergic neurons. AChE besides cholinergic transmission is related to several non-cholinergic actions such as responses to stress situations. Stress can increase due to free radicals which impair enzyme function (Gutierres et al., 2012, 2014) and lead to disorders in locomotion (Blenau et al., 2012) and fish erratic swimming (Salbego et al., 2010).

Adenosine triphosphate (ATP) is the primary intracellular energy source is which is also one of the most important neurotransmitters in the purinergic system and is responsible for modulating signaling and biosynthetic processes, including vascular homeostasis, cell size maintenance, neuronal signaling, immune function, and protein and lipid modifications (Marcus et al., 2003; Tort, 2011). The enzyme ecto-nucleoside triphosphate diphosphohydrolase (NTPDase) hydrolyzes ATP and adenosine diphosphate (ADP) to adenosine monophosphate (AMP). The resulting AMP is subsequently hydrolyzed to adenosine by ecto-5'nucleotidase (Stefan et al., 2005; Colgan et al., 2006; Schmatz et al., 2009).

Exposure to hyperoxic, anoxic or hypoxic environments may result in oxidative changes because oxygen consumption contributes to the levels of reactive oxygen species (ROS) generated and the antioxidant status of the cells (Wilhelm-Filho et al., 2001, 2002; Lushchak et al., 2001, 2005; Azambuja et al., 2011). The oxidative metabolism of cells is a continuous source of ROS (resulting from the univalent reduction of $\mathrm{O}_{2}$ ) that can damage most cellular components such as carbohydrates, lipids and proteins as well as promoting cell death (Ahmad et al., 2000; Morales et al., 2004). To protect themselves from these highly reactive intermediates, living organisms possess a biochemical defense system consisting of enzymatic and non-enzymatic antioxidants that scavenge any reactive species. However, in several situations, the rate of ROS generation exceeds that of their removal, resulting in oxidative stress (Halliwell \& Gutteridge, 2000; Livingstone, 2001). The most important antioxidant enzymes are superoxide dismutase (SOD), which detoxifies $\mathrm{O}_{2}$; catalase (CAT), which reduces $\mathrm{H}_{2} \mathrm{O}_{2}$; glutathione peroxidase (GPx), which reduces both $\mathrm{H}_{2} \mathrm{O}_{2}$ and organic peroxides by a glutathione-dependent reaction; and glutathione reductase (GR), which catalyzes the NADPHdependent regeneration of glutathione (a nonprotein thiol[NPSH]) from the oxidized form (GSSG) generated by GPx (Halliwell \& Gutteridge, 2000).

Variations in the water parameters, such as ammonia and carbon dioxide levels, can provoke stress that could be minimized, at least in some species, through the addition of either sedatives or anesthetics in the transport water (Azambuja et al., 2011; Cunha et al., 2011; Becker et al., 2012). The essential oil (EO) from Lippia alba (Mill.) N.E. Brown (Verbenaceae) is a novel anesthetic whose action has been established for the silver catfish Rhamdia quelen (Cunha et al., 2010; Heldwein et al., 2012), and the slender seahorse Hippocampus reidi (Cunha et al., 2011). When this oil was added to the transport water, the redox state (Azambuja et al., 2011) and ionoregulation (Becker et al., 2012) were improved, and lipid oxidation was delayed in the fillets of silver catfish (Veeck et al., 2013). However, an increased ventilation rate was observed during the $30 \mathrm{~min}$ of transport (Becker et al., 2012).

Increases in the plasma cortisol and glucose levels are classics indicators of stress responses (Iwama et al., 2004; Urbinati \& Carneiro, 2004; Tort, 2011). However, other biochemical parameters, such as enzymatic activities, are also important to understand stress at the cellular level (Lushchak et al., 2001, 2005). In this context, the purpose of this study was to investigate if a rapid pre-transport sedation and transport with the EO from $L$. alba could change enzymes related to purinergic neurotransmitters in the whole brain (AChE, NTPDase and 5'-nucleotidase activities) and improve enzymatic parameters (SOD, CAT, GST, and GPx) that act by inactivating free radicals, in the liver. Furthermore, this study also measured non-enzymatic parameters that can repair damage caused by oxidative stress (NPSH and ascorbic acid), changes in pro-oxidant parameters, such as thiobarbituric acid-reactive substance (TBARS) levels and protein oxidation resulting from damage to lipids and proteins respectively, in the liver of Rhamdia quelen after transport.

\section{Material and Methods}

Essential oil extraction. Lippia alba was cultivated in São Luiz Gonzaga, Rio Grande do Sul State, Brazil. The aerial parts of the plant were collected in January 2009. The plant material was identified by botanist Dr. Gilberto Dolejal Zanetti, Department of Industrial Pharmacy, Universidade Federal de Santa Maria (UFSM), and a voucher specimen (SMDB N ${ }^{\circ}$. 10050) was deposited in the herbarium of the Department of Biology, UFSM.

Essential oil (EO) was obtained from the fresh leaves of the plant by steam distillation for $2 \mathrm{~h}$ using a Clevenger-type apparatus. In this method, the distillate is collected and the aqueous phase is automatically reused by returning it to the distillation flask (European Pharmacopoeia, 2007). The EO samples were stored at $-4^{\circ} \mathrm{C}$ in amber glass bottles. 
Experimental procedure. Silver catfish (mean weight \pm SEM $420.1 \pm 8.8 \mathrm{~g} ; 21.2 \pm 2.3 \mathrm{~cm}$ mean length $\pm \mathrm{SEM}$ ) were captured from a cage net at a fish farm. Fish did not go through a depuration period because this procedure, despite its recommendation (Amend et al., 1982), is not implemented by most fish producers in southern Brazil (Golombieski et al., 2003). Fish were transported at a loading density of $275.1 \mathrm{~g} \mathrm{~L}$ ${ }^{1}$ for $6 \mathrm{~h}$ in 9 plastic bags with $7 \mathrm{~L}$ of water and $8 \mathrm{~L}$ of pure oxygen, and they were divided into three treatment groups (three replicates each, $\mathrm{n}=12$ per group) that were treated with different concentrations of EO from L. alba: control, $30 \mu \mathrm{LL}^{-}$ ${ }^{1}$ and $40 \mu \mathrm{LL}^{-1}$ of EO from L. alba diluted 1:10 in ethanol. Fish that were transported with either of the EO treatments were rapidly sedated with a higher concentration of the same EO (200 $\mu \mathrm{L} \mathrm{L}^{-1}$ ) for three minutes before placing them into the plastic bags. This concentration induces sedation within the time proposed (Cunha et al., 2010). Control fish were placed directly into the plastic bags. The transport time and concentrations of $\mathrm{EO}$ from $L$. alba were chosen according to Becker et al. (2012) and were within a sedative safe range for silver catfish (Cunha et al., 2010). The loading density was chosen according to Carneiro et al. (2009).

Water parameters were monitored before and after transport, with the values (mean $\pm \mathrm{SEM}$ ) at the end of transport as follows: dissolved oxygen $\left(8.29 \pm 0.98 \mathrm{mg} \mathrm{L}^{-1}\right)$, carbon dioxide $\left(58.13 \pm 2.51 \mathrm{mg} \mathrm{L}^{-1}\right)$, alkalinity $\left(30.89 \pm 2.09 \mathrm{mg} \mathrm{CaCO}_{3}\right.$ $\left.\mathrm{L}^{-1}\right)$, water hardness $\left(22.78 \pm 1.64 \mathrm{mg} \mathrm{CaCO}_{3} \mathrm{~L}^{-1}\right), \mathrm{pH}(6.07 \pm$ $0.07)$, temperature $\left(26.33 \pm 0.81{ }^{\circ} \mathrm{C}\right)$, total ammonia nitrogen $\left(3.21 \pm 0.16 \mathrm{mg} \mathrm{L}^{-1}\right)$ and un-ionized ammonia $(0.0023 \pm 0.0002$ $\left.\mathrm{mg} \mathrm{L}^{-1}\right)$. Dissolved oxygen and temperature were measured with an YSI oxygen meter. The $\mathrm{pH}$ was verified with a DMPH$2 \mathrm{pH}$ meter. Nesslerization was used to verify the total ammonia nitrogen levels using the method of Eaton et al. (2005). Unionized ammonia levels were calculated according to Colt (2002). Water hardness was analyzed by the EDTA titrimetric method. Alkalinity was determined according to Boyd \& Tucker (1992). Carbon dioxide was calculated by the method of Wurts \& Durborow (1992).

After transport, all of the fish were euthanized by spinal cord section, and whole brain and liver tissues were carefully removed and frozen to posterior analysis of biochemical parameters.

\section{Enzymatic assays in the brain}

Acetylcholinesterase (AChE; E.C. 3.1.1.7). Brain was homogenized with $150 \mathrm{mM} \mathrm{NaCl}$. The homogenates were centrifuged for $15 \mathrm{~min}$ at $3000 \mathrm{~g}$ at $5{ }^{\circ} \mathrm{C}$, and the supernatant was used as the enzyme source. AChE activity was measured as described by Ellman et al. (1961).

NTPDase (ecto-apyrase, ecto/CD39; E.C. 3.6.1.5). Enzymatic assay of the whole brain was carried out in a reaction medium containing $5 \mathrm{mM} \mathrm{KCl}, 1.5 \mathrm{mM} \mathrm{CaCl}_{2}, 0.1 \mathrm{mM}$ EDTA, $10 \mathrm{mM}$ glucose, $225 \mathrm{mM}$ sucrose and $45 \mathrm{mM}$ Tris- $\mathrm{HCl}$ buffer ( $\mathrm{pH} 8.0$ ) in a final volume of $200 \mu \mathrm{L}$, as described by Schetinger et al. (2000). 5'-nucleotidase (CD73; E.C. 3.1.3.5). Activity was determined by the method of Heymann et al. (1984) in a reaction medium containing $10 \mathrm{mM} \mathrm{MgSO}_{4}$ and $100 \mathrm{mM}$ Tris-HCl buffer (pH 7.5) in a final volume of $200 \mu \mathrm{L}$. The tubes were then chilled on ice for $10 \mathrm{~min}$, and the released inorganic phosphates (Pi) were assayed by the method of Chan et al. (1986).

\section{Enzymatic antioxidant activity in the liver}

Superoxide dismutase (SOD; E.C. 1.15.1.1). Activity was determined as the inhibition rate of autocatalytic adenochrome generation at $480 \mathrm{~nm}$ in a reaction medium containing $1 \mathrm{mM}$ epinephrine $(0.017 \mathrm{~mL})$ and $50 \mathrm{mM}$ glycine- $\mathrm{NaOH}(\mathrm{pH} 10.5)(1$ $\mathrm{mL}$ ). A unit of SOD is defined as the amount of enzyme that inhibits the speed of detector (epinephrine) reduction by $50 \%$. Enzyme activity was expressed in units $\mathrm{mg}$ protein $^{-1}$ using the method described by Misra \& Fridovich (1972).

Catalase (CAT; E.C. 1.11.1.6). Activity was assayed by ultraviolet spectrophotometry. Change of $\mathrm{H}_{2} \mathrm{O}_{2}$ absorbance after $60 \mathrm{~s}$ was measured at $240 \mathrm{~nm}$. Catalase activity was calculated and expressed in $\mu \mathrm{mol} \mathrm{min}^{-1} \mathrm{mg}_{\text {protein }}{ }^{-1}$ using the method described by Nelson \& Kiesow (1972).

Glutathione-S-transferase (GST). Activity was measured based on the method described by Habig et al. (1974) using 1-chloro-2,4-dinitrobenzene (CDNB) $(0.15 \mathrm{~mL})$ as a substrate. The extinction coefficient used for CDNB was $9.6 \mathrm{mM} \mathrm{cm}^{1}$, and the activity was expressed as $\mu \mathrm{mol}$ GS-DNB $\mathrm{min}^{-1} \mathrm{mg}$ protein $^{-1}$.

Glutathione peroxidase (GPx; EC 1.11.1.9). The enzyme activity was measured according to Paglia \& Valentine (1967). The assay solution contained $100 \mathrm{mM}$ potassium phosphate buffer (pH 7.0) $1 \mathrm{mM} \mathrm{GSH}, 0.15 \mathrm{mM}$ NADPH, $0.1 \mathrm{U} \mathrm{mL}^{-1}$ glutathione reductase, $100 \mathrm{mM}$ azide and a suitable sample of enzyme solution. Enzyme activity was determined at $37^{\circ} \mathrm{C}$ by measuring the depletion of NADPH at $340 \mathrm{~nm}$ and expressed as $\mu \mathrm{mol} \mathrm{NADPH} \mathrm{min}^{-1} \mathrm{mg}$ protein ${ }^{-1}$.

\section{Nonenzymatic antioxidants in the liver}

Non-protein thiol groups (NPSH). NPSH levels were determined by the method of Ellman (1959) with $0.05 \mathrm{~mL}$ of 10 $\mathrm{mM} 5$, 5'-dithio-bis (2-nitrobenzoic acid) (DTNB) and $0.7 \mathrm{~mL}$ of $0.5 \mathrm{mM}$ phosphate buffer ( $\mathrm{pH} 6.8$ ) added to $0.25 \mathrm{~mL}$ of supernatant. The results were expressed as $\mu \mathrm{mol}$ non-protein thiols $\mathrm{g}$ tissue $^{-1}$.

Ascorbic acid content (AsA). It was determined by the method of Roe (1954). To measure the ascorbic acid levels, an aliquot of the supernatant was mixed with 2,4dinitrophenylhydrazine $\left(4.5 \mathrm{mg} \mathrm{mL}^{-1}\right), 0.6 \mathrm{mg} \mathrm{mL}^{-1}$ thiourea, $\mathrm{CuSO}_{4}\left(0.075 \mathrm{mg} \mathrm{mL}^{-1}\right)$, and $13.3 \%$ trichloroacetic acid followed by incubation for $3 \mathrm{~h}$ at $37^{\circ} \mathrm{C}$. Afterwards, $\mathrm{H}_{2} \mathrm{SO}_{4} 65 \%(\mathrm{v} / \mathrm{v})$ was added to the medium. The results were expressed as $\mu \mathrm{mol}$ AsA g tissue ${ }^{-1}$.

\section{Prooxidants in the liver}

Lipid peroxidation estimation. The lipid peroxidation was estimated by a thiobarbituric acid-reactive substances 
(TBARS) assay and performed by a malondialdehyde (MDA) reaction with 2-thiobarbituric acid (TBA), which was optically measured according to Buege \& Aust (1978). TBARS levels were expressed as nmol MDA mg protein ${ }^{-1}$.

Protein carbonyl assay. The protein carbonyl content was assayed by the method described by Yan et al. (1995). The assay was performed in duplicate, and two blank tubes treated with $2 \mathrm{~N} \mathrm{HCl}(0.2 \mathrm{~mL})$ without DNPH were included for each sample. The total carbonylation was calculated using a molar extinction coefficient of $22000 \mathrm{M} \mathrm{cm}^{-1}$. The protein carbonyl content was expressed as nmol carbonyl $\mathrm{mg}_{\text {protein }}{ }^{-1}$.

Protein total determination. The protein concentration was determined by the Coomassie Blue method following the Bradford method (1976) using bovine serum albumin as a standard, and the absorbance of the samples was measured at $595 \mathrm{~nm}$.

Statistical analyses. All data are expressed as the mean \pm SEM. The homogeneity of variances between treatments was tested with Levene's test. The data presented homogeneous variances, so comparisons between the different treatments were made using a one way ANOVA and Tukey's test. Analysis was performed using the Statistica ver. 7.0 software (Stat Soft, Tulsa, OK), and the minimum significance level was set at $\mathrm{P}<0.05$.

\section{Results}

No mortality was recorded in any treatment following transport. The AChE, NTPDase and 5'-nucleotidase activities in the whole brain of silver catfish showed no significant differences between the treatments (Table 1).

The SOD activity in the liver did not present any significant difference between the treatments (Fig. 1A), and CAT activity was significantly lower in fish transported with both EO concentrations compared to the control fish (Fig. 1B).The GST activity in the liver was significantly lower in

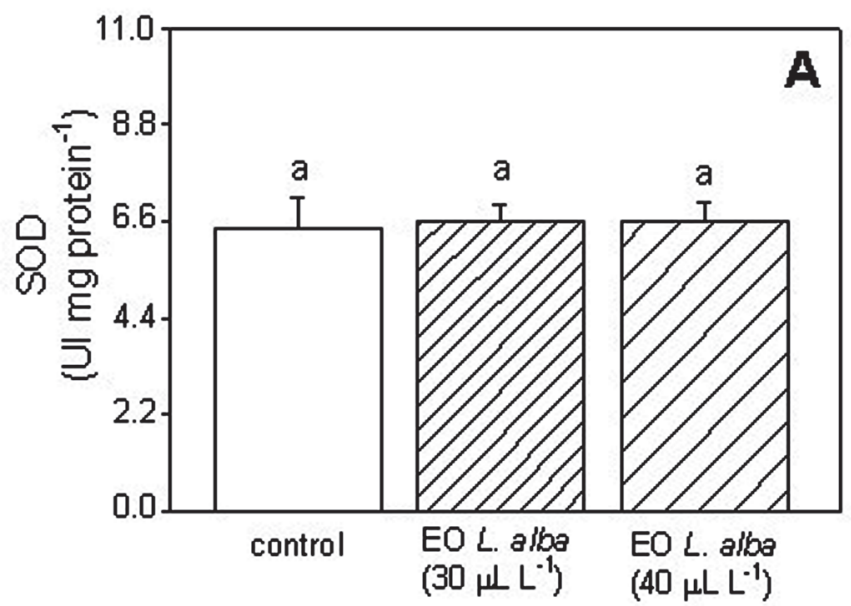

Table 1. Enzymatic activity in the brain. The levels of AChE expressed as $\mu \mathrm{mol}$ ASCh hydrolyzed min $^{-1} \mathrm{mg}$ protein ${ }^{-1}$ and the levels of NTPDase and 5'-nucleotidase activity using either ATP or ADP and AMP as substrates, respectively (values expressed as nmol Pi min $^{-1} \mathrm{mg}$ protein ${ }^{-1}$ ).

\begin{tabular}{lccc}
\hline & \multicolumn{3}{c}{ Lippia alba concentration } \\
& $0 \mu \mathrm{L} \mathrm{L}^{-1}$ & $30 \mu \mathrm{L} \mathrm{L}^{-1}$ & $40 \mu \mathrm{L} \mathrm{L}^{-1}$ \\
\hline AChE & $0.301 \pm 0.014$ & $0.296 \pm 0.010$ & $0.306 \pm 0.019$ \\
NTPDase- ATP & $201.51 \pm 24.51$ & $233.85 \pm 28.29$ & $257.85 \pm 41.85$ \\
NTPDase- ADP & $81.60 \pm 5.43$ & $101.10 \pm 8.82$ & $96.18 \pm 4.65$ \\
5'nucleotidase- AMP & $64.35 \pm 8.16$ & $65.25 \pm 5.58$ & $54.12 \pm 4.80$ \\
\hline
\end{tabular}

silver catfish transported with $30 \mu \mathrm{L} \mathrm{L}^{-1}$ of EO compared to the control fish (Fig. 2A). The GPx activity in the liver was significantly lower in all EO treatments compared to the control (Fig. 2B). Moreover, the lowest activity was observed in fish transported with $40 \mu \mathrm{L} \mathrm{L}^{-1}$ of EO (Fig. 2B). The levels of NPSH and ascorbic acid in the liver were significantly lower in fish transported with both concentrations of EO compared to the control (Fig. 2C-D).

The TBARS and protein carbonyl levels in the liver were higher in the fish transported in water treated with $30 \mu \mathrm{L} \mathrm{L}^{-1}$ of EO from $L$. alba compared to the control group, but the fish transported in water treated with $40 \mu \mathrm{L} \mathrm{L}^{-1}$ of EO showed similar results to the control (Fig. 3A-B). The LPO/CAT + GPx ratio indicated that the balance between lipoperoxidation and total antioxidant enzyme activities was significantly higher in treatments with either 30 or $40 \mu \mathrm{L} \mathrm{L}^{-1}$ of EO compared to the control fish (Fig. 4).

\section{Discussion}

Generally, anesthetics cause a depression of the central nervous system by interrupting the action potential of axons, release of neurotransmitters, excitability of the membrane or a combination of all of these actions (Ross \& Ross, 2008). However, in the present study, the EO from Lippia alba had

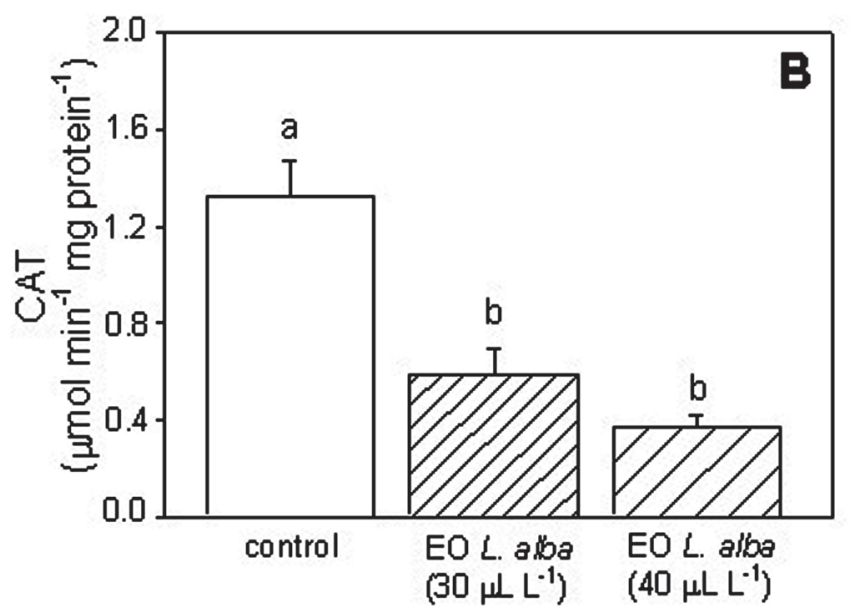

Fig. 1. Superoxide dismutase (SOD) and catalase (CAT) activities (A and B, respectively) in the liver of silver catfish (Rhamdia quelen) transported in plastic bags containing water treated with the essential oil from Lippia alba. The values are expressed as the means \pm SEM. Different letters indicate levels of significance between the treatments $(\mathrm{P}<0.05)$. 

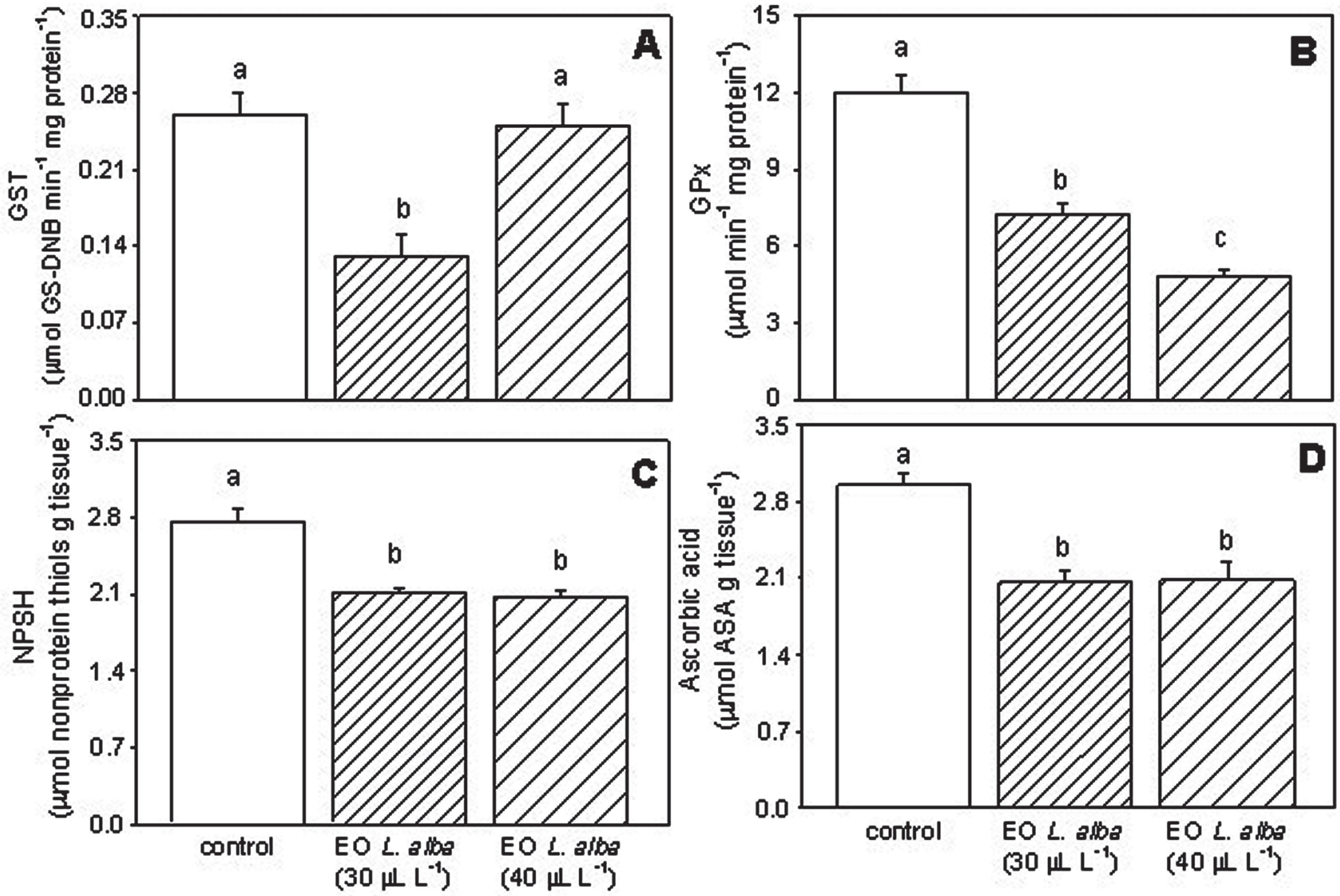

Fig. 2. Glutathione-S-transferase (GST) activity (A), glutathione peroxidase (GPx) activity (B), non-protein thiol group (NPSH) content (C) and ascorbic acid (D) content in the liver of silver catfish (Rhamdia quelen) transported in plastic bags containing water treated with the essential oil from Lippia alba. The values are expressed as the means \pm SEM. Different letters indicate levels of significance between the treatments $(\mathrm{P}<0.05)$.
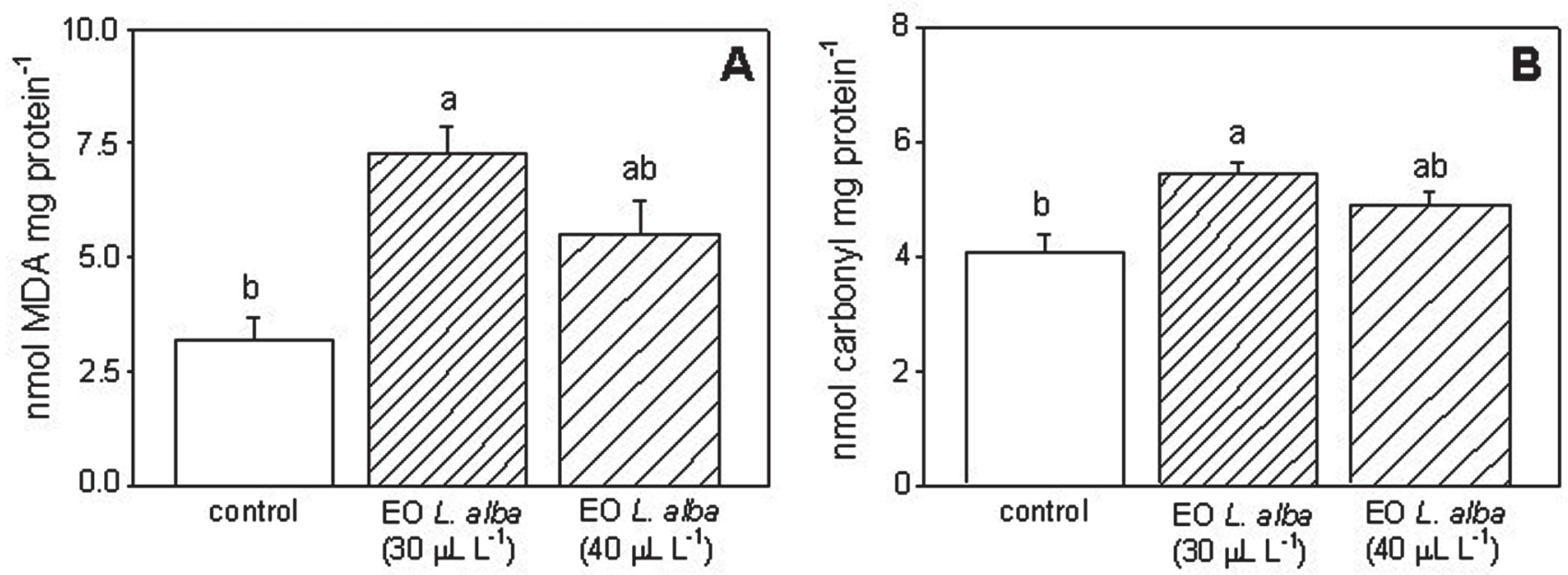

Fig. 3. TBARS (A) and protein carbonilation (B) levels in the liver of silver catfish (Rhamdia quelen) transported in plastic bags containing water treated with the essential oil from Lippia alba. The values are expressed as the means \pm SEM. Different letters indicate difference levels of significance between the treatments $(\mathrm{P}<0.05)$. 


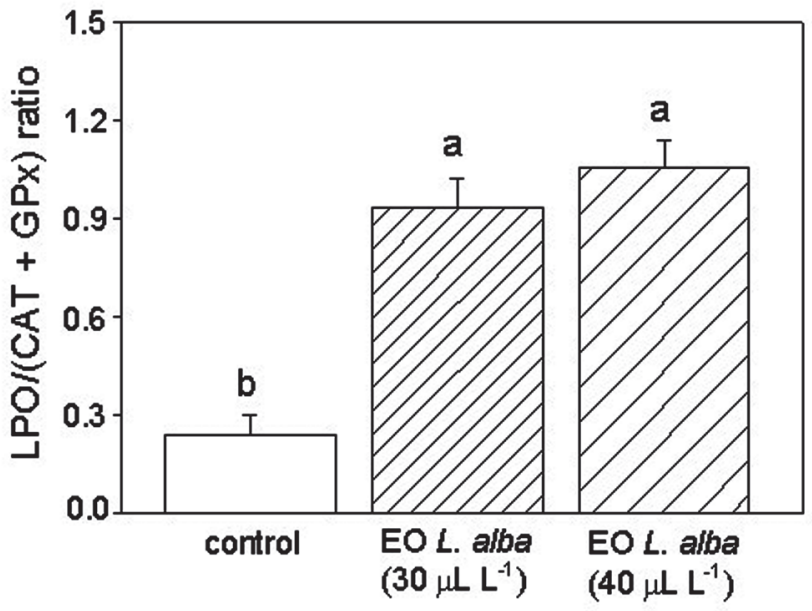

Fig. 4. $\mathrm{LPO} / \mathrm{CAT}+\mathrm{GPx}$ ratio in the liver of silver catfish (Rhamdia quelen) transported in plastic bags containing water treated with the essential oil from Lippia alba. The values are expressed as the means \pm SEM. Different letters indicate levels of significance between the treatments $(\mathrm{P}<0.05)$.

no effect on the activities of the enzymes NTPDase and 5'nucleotidase, which constitute an enzymatic complex able to regulate the extracellular concentrations of adenine nucleotides and nucleosides (Stefan et al., 2005; Colgan et al., 2006; Schmatz et al., 2009; Gutierres et al. 2012, 2014).

Studies by Heldwein et al. (2012) suggest the involvement of the gamma-aminobutyric acid-A $\left(\mathrm{GABA}_{\mathrm{A}}\right)$ benzodiazepine receptor in the anesthetic effect of the EO from $L$. alba. Silver catfish transported in water containing the EO from $L$. alba were less agitated (Becker et al., 2012). The results of the $\mathrm{AChE}$ activity assay corroborate with the aforementioned findings because the enzyme activity was unaltered and the change in the locomotor behavior was not due to alterations in its function. Furthermore, consolidates that EO from $L$. alba is able to reduce or maintain the basal levels of the cholinergic neurotransmitters.

This study did not detect any significant differences in the SOD activity between the treatments after transport of the catfish. The lower CAT and GST activities in the liver of silver catfish transported with $30 \mu \mathrm{L} \mathrm{L}^{-1}$ of EO in the water could be attributed to the increase of the oxidant levels, as observed by the highest levels of TBARS that were generated by this treatment. It is possible that in silver catfish transported with $40 \mu \mathrm{L} \mathrm{L}^{-1}$ of EO in the water the decrease of CAT was enough to avoid the increase of TBARS. Azambuja et al. (2011) reported that silver catfish transported (fish density $\left.140-200 \mathrm{~g} \mathrm{~L}^{-1}\right)$ for $6 \mathrm{~h}$ in normoxic conditions with $10 \mu \mathrm{L} \mathrm{L}^{-1}$ of EO of $L$. alba exhibited no significant alterations in hepatic GST, SOD and CAT activities, but TBARS levels also did not change.

Alterations in GPx activity are generally accompanied by changes in NPSH levels because the NPSH is a co-substrate for $\mathrm{H}_{2} \mathrm{O}_{2}$ breakdown by GPx (Sies, 1999). The major cellular thiol that participates in cellular redox reactions - NPSH displayed an important role in the detoxification of electrophilic metabolites catalyzed by GST (Sies, 1999; Latha $\&$ Pari, 2004).

High NPSH levels may protect cellular proteins against oxidation either via the NPSH redox cycle or by directly detoxifying the ROS generated by exposure to stressor agents (Ruas et al., 2008), but the low NPSH content could modulate the activity of GPx and GST enzymes (Brouwer \& Brouwer, 1998) as suggested in the present study in silver catfish transported in water containing the EO from L. alba. The formation of peroxides and TBARS was lower in the frozen fillets of silver catfish transported with either 30 or $40 \mu \mathrm{L} \mathrm{L}^{-1}$ of EO (Veeck et al., 2013). In the present study, lower levels of ascorbic acid were also observed in the liver of silver catfish transported in water containing the EO from $L$. alba. Antioxidants such as ascorbic acid are active ROS scavengers involved in the lipid peroxidation process (Halliwell \& Gutteridge, 2000; Trenzado et al., 2006; Kochhann et al., 2009). This study showed that the TBARS and protein carbonyl levels in the liver of silver catfish were higher when transported in water containing $30 \mu \mathrm{L} \mathrm{L}^{-1}$ of EO, indicating higher lipid peroxidation and protein oxidation activity and demonstrating that the antioxidant defenses were not completely able to effectively scavenge the ROS produced. The increased $\mathrm{LPO} / \mathrm{CAT}+\mathrm{GPx}$ ratio also suggests that hydrogen peroxide were produced, overcoming the capacity of CAT and GPx in neutralizing ROS production (Ruas et al., 2008) and resulting in a LPO in the liver.

The use of $10-20 \mu \mathrm{L} \mathrm{L}^{-1}$ of EO from L. alba increased ventilation rate of silver catfish during the first $30 \mathrm{~min}$ of transport, indicating a higher agitation of the fish (Becker et al., 2012). Therefore, it was hypothesized that the use of a pre-transport sedation with $200 \mu \mathrm{L} \mathrm{L}^{-1}$ of EO from L. alba would reduce this initial agitation and the transport with 30 or $40 \mu \mathrm{L} \mathrm{L}^{-1}$ of EO from L. alba in the water would be more effective. However, this hypothesis was not confirmed considering the hepatic oxidative stress parameters analyzed in the present experiment and the lower concentrations (10$20 \mu \mathrm{L} \mathrm{L}^{-1}$ of EO from L. alba) used by Azambuja et al. (2011) and Becker et al. (2012) are more effective for transporting silver catfish.

\section{Acknowledgments}

This study was supported by research funds from the Fundação de Amparo à Pesquisa do Estado do Rio Grande do Sul (FAPERGS/PRONEX, process 10/0016-8), the Conselho Nacional de Desenvolvimento Científico e Tecnológico (CNPq, process 470964/2009-0) and the Ministério da Pesca e Aquicultura/FINEP (process 01.12.0130.00). B. Baldisserotto, V. Loro, M. R. C. Schetinger, V. M. Morsch, B. M. Heinzmann, and R. M. Spanevello received research fellowship. J. Salbego, J. F. Gonçalves, and C. G. Heldwein received fellowship from Coordenação de Aperfeiçoamento de Pessoal de Nível 
Superior (CAPES). A. G. Becker and C. C. Menezes received fellowship from CNPq. The authors are grateful to Dr. Gilberto Dolejal Zanetti for the identification of Lippia alba.

\section{Literature Cited}

Ahmad, I., T. Hamid, M. Fatima, H. S. Chand, S. K. Jain, M. Athar \& S. Raisuddin. 2000. Induction of hepatic antioxidants in freshwater catfish (Channa punctatus Bloch) is a biomarker of paper mill effluent exposure. Biochemystry Biophysics Acta, 1523: 37-38.

Amend, N. F., T. R. Croy, B. A. Goven, K. A. Johnson \& D. H. McCarthy. 1982. Transportation of fish in closed systems: methods to control ammonia, carbon dioxide, $\mathrm{pH}$ and bacterial growth. Transactions of the American Fisheries Society, 111: 603-611.

Azambuja, C. R., J. Mattiazzi, A. P. K. Riffel, I. A. Finamor, L. O. Garcia, C. G. Heldwein, B. M. Heinzmann, B. Baldisserotto, M. A. Pavanato \& S. F. Llesuy. 2011. Effect of the essential oil of Lippia alba on oxidative stress parameters in silver catfish (Rhamdia quelen) subjected to transport. Aquaculture, 319: 156161.

Bainy, A. C. D., E. Saito, P. S. M. Carvalho \& V. B. C. Junqueira. 1996. Oxidative stress in gill, erythrocytes, liver and kidney of Nile tilapia (Oreochromis niloticus) from a polluted site. Aquatic Toxicology, 34: 151-162.

Becker, A. G., T. V. Parodi, C. G. Heldwein, C. C. Zeppenfeld, B. M. Heinzmann \& B. Baldisserotto. 2012. Transportation of silver catfish, Rhamdia quelen, in water with eugenol and the essential oil of Lippia alba. Fish Physiology and Biochemistry, 38: 789-796.

Blenau, W., E. Rademacher \& A. Baumann. 2012. Plant essential oils and formamidines as insecticides/ acaricides: what are the molecular targets? Apidologie, 43: 334-347.

Boyd, C. E. \& C. S. Tucker. 1992. Water quality and pond soil analyses for aquaculture. Alabama Agricultural Experiment Station, Auburn University, Alabama, USA.

Bradford, M. M. 1976. A rapid and sensitive method for the quantitation of microgram quantities of protein utilizing the principle of protein-dye binding. Analytical Biochemistry, 72: 248-254.

Brouwer, M. \& T. H. Brouwer. 1998. Biochemical defense mechanisms against copper-induced oxidative damage in the blue crab, Callinectes sapidus. Archives of Biochemistry and Biophysics, 351: 257-264.

Buege, J.A. \& S.D. Aust. 1978. Microssomal lipid peroxidation. Methodos in Enzymology, 52: 302-309.

Carneiro, P. C. F., P. H. S. Kaiseler, E. A. C. Swarofsky \& B. Baldisserotto. 2009. Transport of jundiá Rhamdia quelen juveniles at different loading densities: water quality and blood parameters. Neotropical Ichthyology, 7: 283-288.

Chan, K., D. Delfert \& K. D. Junger. 1986. A direct colorimetric assay for $\mathrm{Ca}^{2+}$-NTPase activity. Analytical Biochemistry, 157: 375-378.

Colt, J. 2009. List of spreadsheets prepared as a complement. In: Wedemeyer, G. A. (Ed.). Fish hatchery management, $2^{\text {nd }}$ ed. American Fisheries Society Publisher. Available from: http:// www.sheries.org/afs/hatchery.html (September 26, 2013).

Colgan, S. P., H. K., H. K. Eltzschig, T. Eckle \& L. F. Thompson. 2006. Physiological roles for ecto-5'-nucleotidase (CD 73). Purinergic Signal, 2: 351-360.
Cunha, M. A., F. M. C. Barros, L. O. Garcia, A. P. L. Veeck, B. M. Heinzmann, V. L. Loro, T. Emanuelli \& B. Baldisserotto. 2010. Essential oil of Lippia alba: a new anesthetic for silver catsh, Rhamdia quelen. Aquaculture, 306: 403-406.

Cunha, M. A., B. F. Silva, F. A. C. Delunardo, S. C. Benovit, L. C. Gomes, B. M. Heinzmann \& B. Baldisserotto. 2011. Anesthetic induction and recovery of Hippocampus reidi exposed to the essential oil of Lippia alba. Neotropical Ichthyology, 9: 683688.

Eaton, A. D., L. S. Clesceri, E. W. Rice \& A. E. Greenberg. 2005. Standard methods for the examination of water and wastewater, $21^{\text {st }}$ ed. American Public Health Association, USA. 1368p.

Ellman, G. L. 1959. Tissue sulfhydryl groups. Archives of Biochemistry and Biophysis, 82: 70-77.

Ellman, G. L., K. D. Courtney Jr., V. Andres \& R. M. Featherstone. 1961. A new and rapid colorimetric determination of acetylcholinesterase activity. Biochemical Pharmacology, 7: 8895.

European Pharmacopoeia. 2007. $6^{\text {th }}$ ed. Strassbourg, European Directorate for the Quality of Medicines.

Golombieski, J. I., L. V. F. Silva, B. Baldisserotto \& J. H. S. da Silva. 2003. Transport of silver catfish (Rhamdia quelen) fingerlings at different times, load densities, and temperatures. Aquaculture, 216: 95-102.

Gutierres, J. M., R. R. Kaiser, C. M. Mazzanti, J. M. Vieira, M. V. Rodrigues, J. Jaques, F. Carvalho, D. Zanini, V. M. Morsch, M. R. C. Schetinger \& R. M. Spanevello. 2012. Alpha-tocopherol regulates ectonucleotidase activities in synaptosomes from rats fed a high-fat diet. Cell Biochemistry and Function, 30: 286292.

Gutierres, J. M., F. B. Carvalho, M. R. C. Schetinger, P. Agostinho, P. C. Marisco, J. M. Vieira, M. M. Rosa, C. Bohnert, M. A. Rubin, V. M. Morsch, R. Spanevello \& C. M. Mazzanti. 2014. Neuroprotective effect of anthocyanins on acetylcholinesterase activity and attenuation of scopolamine-induced amnesia in rats. International Journal of Developmental Neuroscience, 33: 8897.

Habig, W. H., M. J. Pabst \& W. B. Jakoby. 1974. Glutathione Stransferases. The first enzymatic step in mercapturic acid formation. Journal of Biological Chemistry, 249: 7130-7139.

Halliwell, B. \& J. M. C. Gutteridge. 2000. Free Radicals in Biology and Medicine. $3^{\text {rd }}$ ed. Oxford University Press, Oxford, UK.

Heldwein, C. G., L. L. Silva, P. Reckziegel, F. M. C. Barros, M. E. Bürger, B. Baldisserotto, C. A. Mallmann, D. Schmidt, B. O. Caron \& B. M. Heinzmann. 2012. Participation of the GABAergic system in the anesthetic effect of Lippia alba (Mill.) N. E. Brown essential oil. Brazilian Journal of Medical and Biological Research, 45: 436-443.

Heymann, D., M. Reddington \& G. W. Kreutzberg. 1984. Sub cellular localization of 5'-nucleotidase in rat brain. Journal of Neurochemistry, 43: 971-978.

Iwama, G., L. Afonso \& V. Mathilakath. 2004. Stress in fish. Campbell River, Aqua Net Workshop on Fish Welfare. 278p.

Kochhann, D., M. A. Pavanato, S. F. Llesuy, L. M. Correa, A. P. K. Riffel, V. L. Loro, M. F. Mesko, E. M. M. Flores, V. L. Dressler $\&$ B. Baldisserotto. 2009. Bioaccumulation and oxidative stress parameters in silver catfish (Rhamdia quelen) exposed to different thorium concentrations. Chemosphere, 77: 384-391.

Latha, M. \& L. Pari. 2004. Effect of an aqueous extract of Scoparia dulcis on blood glucose, plasma insulin and some polyol pathway enzymes in experimental rat diabetes. Brazilian Journal of Medical Biological Research, 37: 577-586. 
Livingstone, D. R. 2001. Contaminant-stimulated reactive oxygen species production and oxidative damage in aquatic organisms. Marine Pollution Bulletin, 42: 656-666.

Lushchak, V. I., L. P. Lushchak, A. Mota \& M. Hermes-Lima. 2001. Oxidative stress and antioxidant defenses in goldfish Carassius auratus during anoxia and reoxygenation. American Journal of Physiology Regulatory Integrative and Comparative Physiology, 280: 100-107.

Lushchak, V. I., T. V. Bagnyukova, O. V. Lushchak, J. M. Storey \& K. B. Storey. 2005. Hypoxia and recovery perturb free radical process and antioxidant potential in common carp (Cyprinus carpio) tissues. International Journal of Biochemistry \& Cell Biology, 37: 1319-1330.

Marcus, A. J., M. J. Broekman, J. H. F. Drosopoulos, N. Islam, D. J. Pinsky, C. Sesti \& R. Levi. 2003. Heterologous cell-cell interactions: thromboregulation, cerebroprotection and cardioprotection by CD39 (NTPDase-1). Journal of Thrombosis and Haemostasis, 1: 2497-2509.

Misra, H. P. \& I. Fridovich. 1972. The role of superoxide anion in the auto-oxidation of epinephrine and a simple assay for superoxide dismutase. Journal of Biological Chemistry, 247: 3170-3175.

Morales, A. E., A. Pérez-Jiménez, M. C. Hidalgo, E. Abellán \& G. Cardenete. 2004. Oxidative stress and antioxidant defenses after prolonged starvation in Dentex dentex liver. Comparative Biochemistry and Physiology, 139: 153-161.

Nelson, D. P. \& Kiesow, L.A. 1972. Enthalpy of decomposition of hydrogen peroxide by catalase at $25^{\circ} \mathrm{C}$ (with molar extinction coefficients of $\mathrm{H}_{2} \mathrm{O}_{2}$ solution in the UV). Analytical Biochemistry, 49: 474-478.

Nilsson, G. E. \& G. M. C. Renshaw. 2004. Hypoxic survival strategies in two fishes: extreme anoxia tolerance in the North European crucian carp and natural hypoxic preconditioning in a coral-reef shark. Journal of Experimental Biology, 207: 31313139.

Paglia, D. E. \& W. N. Valentine. 1967. Studies on the quantitative and qualitative characterization of erythrocytes glutathione peroxidase. Journal of Laboratory and Clinical Medicine, 70: 158-168.

Roe, J. H. 1954. Chemical determination of ascorbic, dehydroascorbic and diketogulonic acids. Pp. 115-139. In: Glick, D. (Ed.). Methods of Biochemical Analysis. Interscience Publishers Inc., New York.

Ross, L. G. \& B. Ross. 2008. Anaesthetic and sedative techniques for aquatic animals, $3^{\text {rd }}$ ed., Blackwell Publishing Ltd., Oxford.

Ruas, C. B. G., C. S. Carvalho, H. S. S. de Araújo, E. L. G. Espíndola \& M. N. Fernandes. 2008. Oxidative stress biomarkers of exposure in the blood of cichlid species from a metalcontaminated river. Ecotoxicology and Environment Safety, 71: 86-93.

Salbego, J., A. Pretto, C. R. Gioda, C. C. Menezes, R. Lazzari, J. Radünz Neto, B. Baldisserotto \& V. L. Loro. 2010. Herbicide formulation with glyphosate affects growth, acetylcholinesterase activity, and metabolic and hematological parameters in piava (Leporinus obtusidens). Archives of Environmental Contamination and Toxicology, 58: 740-745.

Schetinger, M. R. C., N. M. Porto, M. B. Moretto, V. M. Morsch, J. B. T. da Rocha, V. Vieira, F. Moro, R. T. Neis, S. Bittencourt, H.G. Bonacorso \& N. Zanatta. 2000. New benzodiazepines alter acetylcholinesterase and ATPDase activities. Neurochemical Research, 25: 949-955.
Schmatz, R., M. R. C. Schetinger, R. M. Spanevello, C. M. Mazzanti, N. Stefanello, P. A. Maldonado, J. Gutierres, M. C. de Carvalho, E. Girotto, M. B. Moretto \& V. M. Morsch. 2009. Effects of resveratrol on nucleotide degrading enzymes in streptozotocin-induced diabetic rats. Life Sciences, 84: $345-$ 350.

Sies, H. 1999. Glutathione and its role in cellular functions. Free Radical Biology and Medicine, 27: 916-921.

Stefan, C., S. Jansen \& M. Bollen. 2005. NPP-type ectophosphodiesterases: unity in diversity. Trends in Biochemical Sciences, 30: 542-550.

Summerfelt, R. C. \& L. S. Smith. 1990. Anesthesia, surgery and related techniques. Pp. 213-272. In: C.B. Schreck, P.B. Moyle (Eds.). Methods for Fish Biology. American Fisheries Society, Bethesda, Maryland.

Trenzado, C., M. C. Hidalgo, M. Garcia-Gallego, A. E. Morales, M. Furné, J. Domezain \& A. Sanz. 2006. Antioxidant enzymes and lipid peroxidation in sturgeon Acipenser naccarii and trout Oncorhynchus mykiss. A comparative study. Aquaculture, 254: 758-767.

Tort, L. Stress and immune modulation in fish. 2011. Developmental \& Comparative Immunology, 35: 1366-1375.

Urbinati, E. C. \& P. C. F. Carneiro. 2004. Práticas de manejo e estresse dos peixes em piscicultura intensiva. Pp. 171-194. In: Cyrino, J. E. P., E. C. Urbinati, D. M. Fracalossi \& N. Castagnolli (Eds.). Tópicos especiais em piscicultura de água doce tropical intensiva. São Paulo: Tec Art.

Veeck, A. P. L., B. Klein, L. F. Ferreira, A. G. Becker, C. G. Heldwein, B. M. Heinzmann, B. Baldisserotto \& T. Emanuelli. 2013. Lipid stability during the frozen storage of fillets from silver catfish exposed in vivo to the essential oil of Lippia alba (Mill.) NE Brown. Journal of the Science of Food and Agriculture, 93: 955960.

Wilhelm Filho, D., T. Tribess, C. Gáspari, F. D. Claudio, M. A. Torres \& A. R. M. Magalhães. 2001. Seasonal changes in antioxidant defenses of the digestive gland of the brown mussel (Perna perna). Aquaculture, 203: 149-158.

Wilhelm Filho, D., F. Sell, L. Ribeiro, M. Ghislandi, F. Carrasquedo, C. G. Fraga, J. P. Wallauer, P. C. Simões-Lopes \& M. M. Uhart. 2002. Comparison between the antioxidant status of terrestrial and diving mammals. Comparative Biochemistry and Physiology, 133: 885-892.

Winkaler, E. U., T. R. M. Santos, J. G. Machado-Neto \& C. B. R. Martinez. 2007. Acute lethal and sublethal effects of neem leaf extract on the neotropical freshwater fish Prochilodus lineatus. Comparative Biochemistry and Physiology, 145: 236-244.

Wurts, W. A. \& R. M. Durborow. 1992. Interactions of pH, carbon dioxide, alkalinity and hardness in fish ponds. Southern Regional Aquaculture Center Publication, 464: 1-4.

Yan, L. J., M. G. Traber \& L. Packer. 1995. Spectrophotometric method for determination of carbonyls in oxidatively modified apolipoprotein B of human low-density lipoproteins. Analytical Biochemistry, 228: 349-351.

Submitted October 4, 2013 Accepted April 20, 2014 by Adalberto L. Val Published December 27, 2014 